\title{
Longevity of wild pansy flowers treated with growth regulators ${ }^{(1)}$
}

\author{
TANIA PIRES DA SILVA ${ }^{(2)^{*}}$, FERNANDA FERREIRA DE ARAÚJO(2), FERNANDO LUIZ FINGER ${ }^{(3)}$
}

\begin{abstract}
The objective of this study was to evaluate the growth regulators action on the senescence of wild pansy flowers. In the first experiment, floral stems were treated with ethylene for 24 hours at concentrations of $0.1,1.0,10,100$ and $1000 \mu \mathrm{L} \mathrm{L}^{-1}$ and control without the hormone. In a second experiment, the flowers were immersed in solutions of abscisic acid (ABA) containing 5, 20, 50 and 100 $\mu \mathrm{M}$ for one minute and control with water. In a third experiment, 1-methylcyclopropene (1-MCP) was applied at concentrations of $0.5,1.0$ and $1.5 \mu \mathrm{L} \mathrm{L}^{-1}$ and control without the chemical. In a fourth experiment, 1-MCP and ethylene were applied, where 1-MCP was first applied followed by ethylene. After the treatments with 1-MCP and ethylene, the floral stems were removed from the hermetic chambers and kept in a vessel containing distilled water at $25{ }^{\circ} \mathrm{C}, 10 \mu \mathrm{mol} \mathrm{m}{ }^{-2} \mathrm{~s}^{-1}$ white fluorescent light and $50-70 \%$ relative humidity as for the ABA treatment. Flowers treated with ethylene did not present significant differences among the concentrations for visual senescence, showing evidence that this flower is not sensitive to ethylene. Treatment with $1000 \mu \mathrm{L} \mathrm{L}^{-1}$ of ethylene led to a slightly higher fresh weight loss than other treatments, which had a loss of about $33 \%$ at end of the experiment. For the ABA treatment, the flowers showed similar fresh weight loss among the different treatments; however, higher concentrations induced slight senescence of flowers. The use of 1-MCP increased the longevity of wild pansy flowers. These results show that 1-MCP is beneficial in maintaining the flower water status, even in the presence of exogenous ethylene, although ethylene may not be directly involved in the senescence of wild pansy flowers.
\end{abstract}

Keywords: Viola tricolor, 1-Methylciclopropene, abscisic acid, ethylene, longevity.

\section{RESUMO}

Longevidade de flores de amor-perfeito submetidas a reguladores de crescimento

Neste trabalho, objetivou-se avaliar a ação de reguladores de crescimento na senescência de flores de amor perfeito (Viola tricolor L.). No primeiro experimento, as hastes florais foram tratadas com etileno por $24 \mathrm{~h}$ nas concentrações 0,$1 ; 1,0 ; 10 ; 100 ; 1000$ $\mu \mathrm{L} \mathrm{L}^{-1}$ e o controle sem o hormônio. No segundo experimento, as flores foram imersas em soluções de diferentes concentrações de ácido abscísico (ABA) contendo 5, 20, 50 e $100 \mu \mathrm{M}$, durante um minuto e o controle com água. No terceiro experimento, o 1-metilciclopropeno (1-MCP) foi aplicado, nas concentrações de 0,$5 ; 1,0 ; 1,5 \mathrm{~g} \mathrm{~m}^{-3}$ e controle sem o químico. No quarto experimento, 1-MCP e etileno foram aplicados, onde o 1-MCP foi aplicado primeiro seguido por etileno. Após os tratamentos com 1-MCP e etileno, as hastes florais foram retiradas das câmaras herméticas e mantidas em recipiente contendo água destilada a $25^{\circ} \mathrm{C}$, $10 \mu \mathrm{mol} \mathrm{m} \mathrm{s}^{-2} \mathrm{~s}^{-1}$ de luz fluorescente branca e $50-70 \%$ de umidade relativa, bem como após o tratamento com ABA. Flores submetidas a diferentes concentrações de etileno não apresentaram diferenças significativas entre os tratamentos quanto a senescência visual, demonstrando indícios que estas são pouco sensíveis ao etileno. O tratamento com $1000 \mu \mathrm{L} \mathrm{L}^{-1}$ levou a uma perda de massa fresca levemente superior em relação aos outros tratamentos os quais tiveram em torno de $33 \%$ de perda ao final do experimento. No experimento com ABA, as flores apresentaram perda de massa fresca semelhante entre os diferentes tratamentos, entretanto, concentrações elevadas levaram a uma breve senescência das flores. O 1-MCP aumentou a longevidade das flores de amor perfeito. Estes resultados mostram que o 1-MCP é benéfico na manutenção da turgescência em flores de amor perfeito, mesmo quando na presença de etileno exógeno, apesar de possivelmente o etileno não estar diretamente envolvido na senescência destas flores.

Palavras-chave: Viola tricolor, 1-Metilciclopropeno, ácido abscísico, etileno, longevidade.

\section{INTRODUCTION}

The gastronomic market is becoming more diversified and innovative and among the products, which increases the demand for edible flowers, i.e. garden nasturtium (Tropaeolum majus) and wild pansy (Viola tricolor). Because of that, a new market for producers arises, demanding increase in production and supply of these products; however, associated with this, there is the concern with the conservation of these flowers, since they are fragile and have extremely short shelf life.

In general, flower petals have at about $80 \%$ water and are subject to rapid deterioration after harvesting. According to Dukovski et al. (2006), postharvest senescence of flowers is

DOI: http://dx.doi.org/10.14295/oh.v24i2.1178

(1) Received in 21/03/2018 and accepted in 10/05/2018

(2) Universidade Federal dos Vales do Jequitinhonha e Mucuri, Instituto de Ciências Agrárias, Unaí-MG, Brazil. *Corresponding author: tania.pires@ ufvjm.edu.br

(3) Universidade Federal de Viçosa, Departamento de Fitotecnia, Viçosa-MG, Brazil.

Licensed by CC BY 4.0 
regulated by many endogenous or external factors that may act synergistically. Thus, factors such damage of biological membranes and the remobilization of macromolecules (VAN DOORN and WOLTERING, 2008), increase in respiration and ethylene production affect the integrity and senescence of the petals.

The mechanisms that control senescence are grouped into two categories: nutritional deficiency and genetic programming, including the action of ethylene, abscisic acid and inhibitors of senescence such as cytokinins, polyamines and calcium ions. In some flower species, petal senescence is highly sensitive to ethylene, while in another group, the petals are insensitive to this hormone, suggesting that senescence is not regulated by this molecule (VAN DOORN and WOLTERING, 2008). According to Kumar et al. (2014), there is an increase of abscisic acid (ABA) in flowers classified as ethylene insensitive throughout senescence.

Postharvest treatments to preserve edible flowers are still extremely scarce. Thus, in order to minimize postharvest losses and increase the shelf life of edible flowers, the objective of this work was to study the determinant factors that affect senescence in wild pansy flowers.

\section{MATERIAL AND METHODS}

Seeds of wild pansy (Viola tricolor) were sown in flat tray containing commercial substrate and after one month, the plants were transplanted to beds, spaced $30 \mathrm{~cm} \times 30 \mathrm{~cm}$ between rows and plants, containing the following mixture 2:1:1 of red-yellow latosol, sand and bovine manure. The experiment was conducted from autumn to spring and the field was located at Federal University of Viçosa (20 45'S, $\left.42^{\circ} 15^{\prime} \mathrm{W}\right)$, Minas Gerais State, Brazil. After 3 months, the newly opened flowers were harvested in the morning at 7:00 a.m.; transported in bottles with water to the laboratory and non-damaged flowers were selected to the following independent experiments.

\section{Experiment 1: Ethylene}

The flowers were exposed to five concentrations of ethylene $\left(0.1,1.0,10,100\right.$ and $\left.1000 \mu \mathrm{L} \mathrm{L}^{-1}\right)$ and control without ethylene. The stems were kept in airtight chambers for 24 hours, in a total of four replicates with 10 stems per vase, in a randomized block design. Then, the floral stems were removed from the airtight chambers and kept in a vase containing distilled water at $25{ }^{\circ} \mathrm{C}, 10 \mu \mathrm{mol} \mathrm{m} \mathrm{m}^{-2} \mathrm{~s}^{-1}$ white fluorescent light and $60 \%$ relative humidity.

\section{Experiment 2: 1-MCP}

The flowers were treated with 1-MCP (Ethylbloc $\AA$, containing $0.14 \%$ of $1-\mathrm{MCP}$ ) at $0.5,1.0$ and $1.5 \mu \mathrm{L} \mathrm{L}^{-1}$ and control without 1-MCP. The stems were kept in airtight chambers for 24 hours, in a total of four replicates with 10 stems per vase, in a randomized block design. Then, the floral stems were removed from the airtight chambers and kept in a vase containing distilled water at $25^{\circ} \mathrm{C}, 10 \mu \mathrm{mol}$ $\mathrm{m}^{-2} \mathrm{~s}^{-1}$ white fluorescent light and $60 \%$ relative humidity.

\section{Experiment 3: 1-MCP + Ethylene}

The third experiment was carried out to evaluate the effects of 1-MCP in the presence of ethylene. The experiment consisted of four treatments, being control in absence of ethylene and 1-MCP; ethylene $\left(100 \mu \mathrm{L} \mathrm{L}^{-1}\right)$; 1-MCP $\left(1.5 \mu \mathrm{L} \mathrm{L}^{-1}\right)$ and $1.5 \mu \mathrm{L} \mathrm{L}^{-1} 1-\mathrm{MCP}+100 \mu \mathrm{L} \mathrm{L}^{-1}$ ethylene. 1-MCP was applied for $24 \mathrm{~h}$, followed by the application of ethylene for $24 \mathrm{~h}$. The ethylene dose of 100 $\mu \mathrm{L} \mathrm{L}^{-1}$ showed the maximum response by the flowers, as the saturating level. Then, the floral stems were removed from the airtight chambers and kept in a vase containing distilled water at $21{ }^{\circ} \mathrm{C}, 10 \mu \mathrm{mol} \mathrm{m} \mathrm{m}^{-2} \mathrm{~s}^{-1}$ white fluorescent light and $62 \%$ relative humidity.

\section{Experiment 4: ABA}

Wild pansy flowers were immersed for one minute in solutions of ABA at 5, 20,50,100 $\mu \mathrm{M}$ and control in water only, then placed in vases with distilled water and maintained at a temperature of $25^{\circ} \mathrm{C}, 10 \mu \mathrm{mol} \mathrm{m} \mathrm{m}^{-2} \mathrm{~s}^{-1}$ of white fluorescent light and relative humidity of $64 \%$.

The flowers were daily weighted and assessed for loss of market quality, including wilting or necrosis of the petals through the assignment of grades according to a visual scale, pre-established by the authors, prior to the experiments. Senescence scale: -1 : withered flowers; -2 : beginning of necrosis at the borders of the petals; -3 : necrosis of up to $50 \%$ of the petals; -4 : completely dry petals; +4 : turgid flowers.

For the fresh weight loss, the stems were weighed daily and the value of the loss (in percentage) was calculated in relation to the first day; its data is presented in percentage and it was submitted to the analysis of descriptive statistics, based on the mean values and standard error. The data referring to the scores attributed through the senescence scale were submitted to ANOVA analysis and the means of treatment were compared by the Tukey test at $5 \%$ probability.

\section{RESULTS AND DISCUSSION}

After 48 hours on the bench, the treatment subjected to $1000 \mu \mathrm{L} \mathrm{L}^{-1}$ of ethylene showed flowers with slightly higher fresh weight loss compared to other concentrations (Figure 1). 


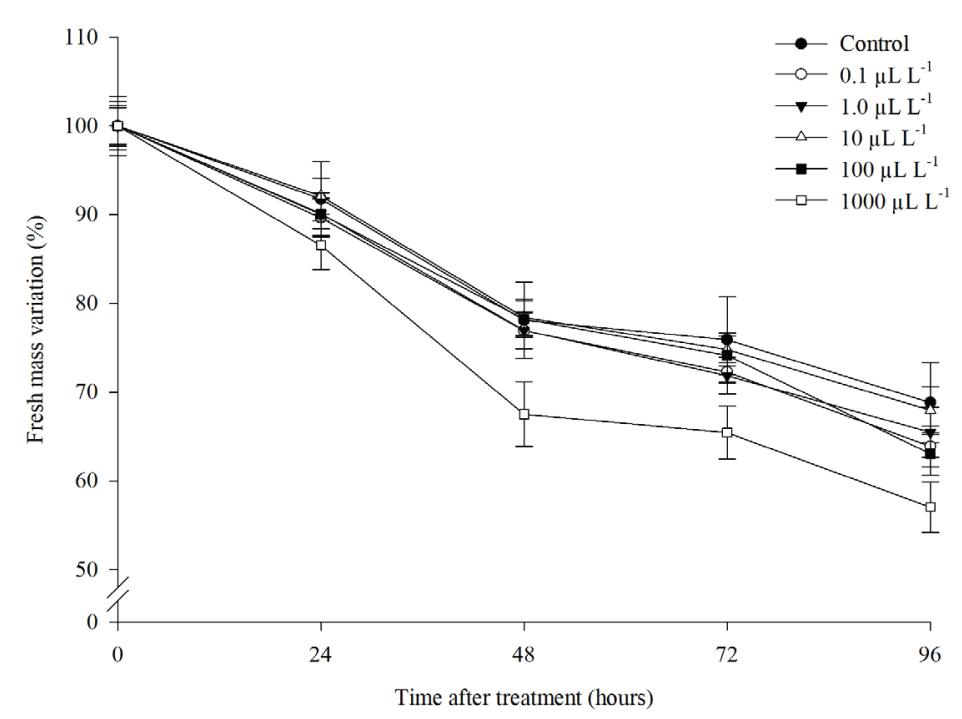

Figure 1. Fresh mass variation (\%) in wild pansy flowers (Viola tricolor) over time, after the application of different doses of ethylene $\left(\mu \mathrm{L} \mathrm{L}^{-1}\right)$. Bars represent standard error.

The remaining ethylene treatments showed similar percentage of fresh weight loss throughout the days, around $33 \%$ at end of the experiment. Flowers exposed to increased concentrations of ethylene did not show significant differences on senescence compared to control (Table 1). In other words, even at the highest concentration of ethylene there was no trigger of senescence, and the flowers remained similar in appearance to the control flowers. These results indicate that wild pansy flower is not sensitive to ethylene, and that this hormone may not be related to its senescence.

Table 1. Averages of notes adopted by wild pansy flowers (Viola tricolor) in the experiments with ethylene, 1-MCP, 1-MCP combined with ethylene and abscisic acid (ABA), obtained 48 hours after application of treatments. Equal letters in the column do not differ by Tukey's test $(\mathrm{p}<0.05)$.

\begin{tabular}{|c|c|}
\hline Ethylene $\left(\mu \mathbf{L ~}^{-1}\right)$ & Mean \\
\hline Control & $-1.3 \mathrm{a}$ \\
\hline 0.1 & $-1.3 \mathrm{a}$ \\
\hline 1.0 & $-2.0 \mathrm{a}$ \\
\hline 10 & $-2.0 \mathrm{a}$ \\
\hline 100 & $-2.3 \mathrm{a}$ \\
\hline 1000 & $-2.6 \mathrm{a}$ \\
\hline 1-MCP $\left(\mu \mathbf{L} \mathbf{L}^{-1}\right)$ & Mean \\
\hline Control & $-2.4 \mathrm{~b}$ \\
\hline 0.5 & $4 \mathrm{a}$ \\
\hline 1.0 & $4 \mathrm{a}$ \\
\hline 1.5 & $4 \mathrm{a}$ \\
\hline 1-MCP + Etileno $\left(\mu \mathrm{L} \mathbf{L}^{-1}\right)$ & Mean \\
\hline Control & $-3 \mathrm{~b}$ \\
\hline $1-M C P$ & $3 \mathrm{a}$ \\
\hline Ethylene & $-3.4 \mathrm{~b}$ \\
\hline 1-MCP + Ethylene & $4 \mathrm{a}$ \\
\hline ABA $(\boldsymbol{\mu M})$ & Mean \\
\hline Control & $2.7 \mathrm{a}$ \\
\hline 5 & $-1 \mathrm{~b}$ \\
\hline 20 & $-1.2 \mathrm{~b}$ \\
\hline 50 & $-1.8 \mathrm{~b}$ \\
\hline 100 & $-2 \mathrm{~b}$ \\
\hline
\end{tabular}


Regardless the concentration of 1-MCP, there was an initial increase in water uptake, followed by a decrease over the days. The dose of $1.5 \mu \mathrm{L} \mathrm{L}^{-1} 1$-MCP provided the lowest variation of fresh weight loss in wild pansy flowers. For the treatment without $1-\mathrm{MCP}$, the flowers showed the highest fresh weight loss.
Even though we assumed that ethylene is probably not responsible for inducing senescence in wild pansy flowers, the treatment with 1-MCP prolonged the postharvest shelf life (Table 1). The 1-MCP acted by improving the water relations in the stems (Figure 2 and 3), by blocking some negative effect of ethylene other than the induction of senescence.

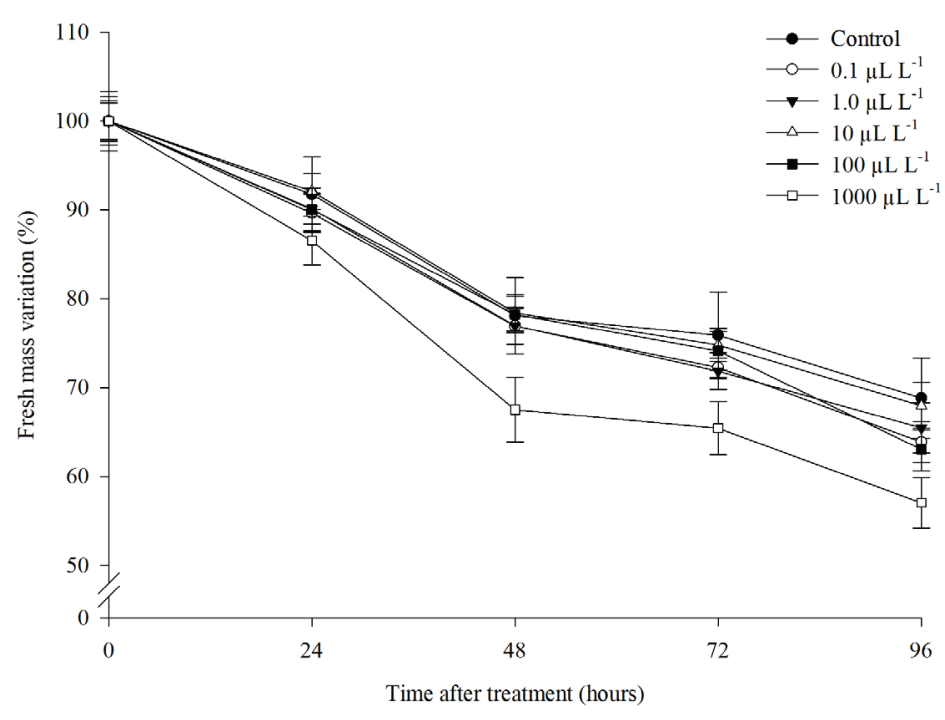

Figure 2. Fresh mass variation (\%) in wild pansy flowers (Viola tricolor) over time, after the application of different doses of 1-MCP $\left(\mu \mathrm{L} \mathrm{L}^{-1}\right)$. Bars represent standard error.

According to Hatamzadeh et al. (2012), lipid peroxidation and membrane stability have been shown to be inversely proportional to floral senescence and according to Hassan (2016), the presence of 1-MCP increased the relative water content, maintained membrane stability index and decreased malondialdehyde in roses.

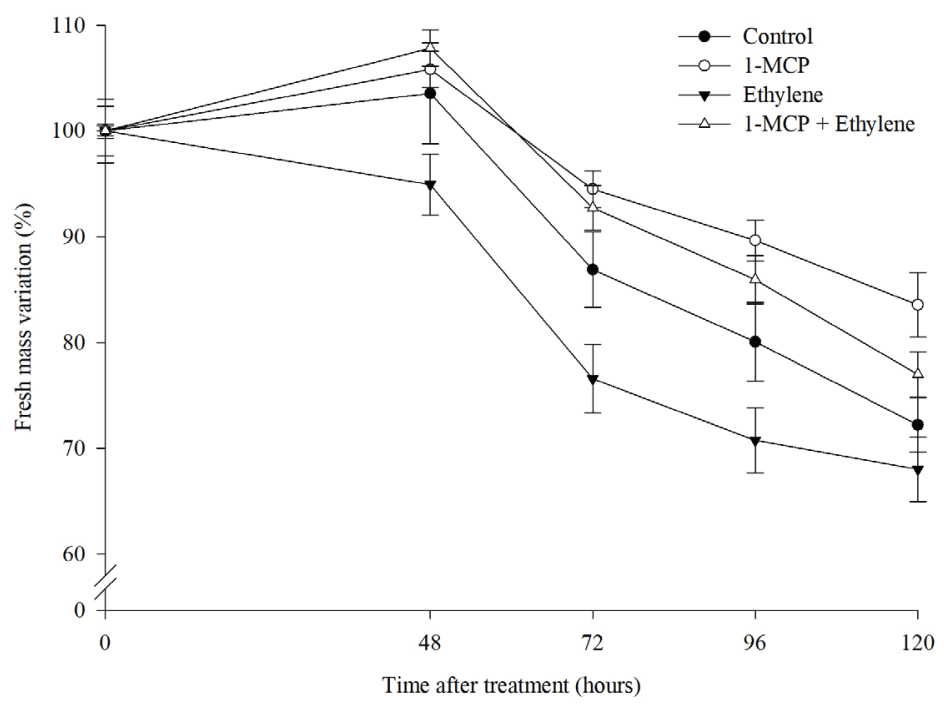

Figure 3. Fresh mass variation (\%) in wild pansy flowers throughout the days, after application of 1-MCP $\left(\mu \mathrm{L} \mathrm{L}^{-1}\right)$, ethylene $\left(\mu \mathrm{L} \mathrm{L}^{-1}\right)$ and 1-MCP combined with ethylene. Bars represent standard error. 
1-MCP was effective in prolonging the shelf life at any applied concentration. After 48 hours from the 1-MCP application, the flowers were turgid, while the control flowers already exhibited necrosis at the edges of the petals (Figure 4). Non-climacteric plant tissue may also synthesize ethylene and, in some cases, ethylene has shown to accelerate postharvest deterioration (TRAINOTTI et al., 2005).

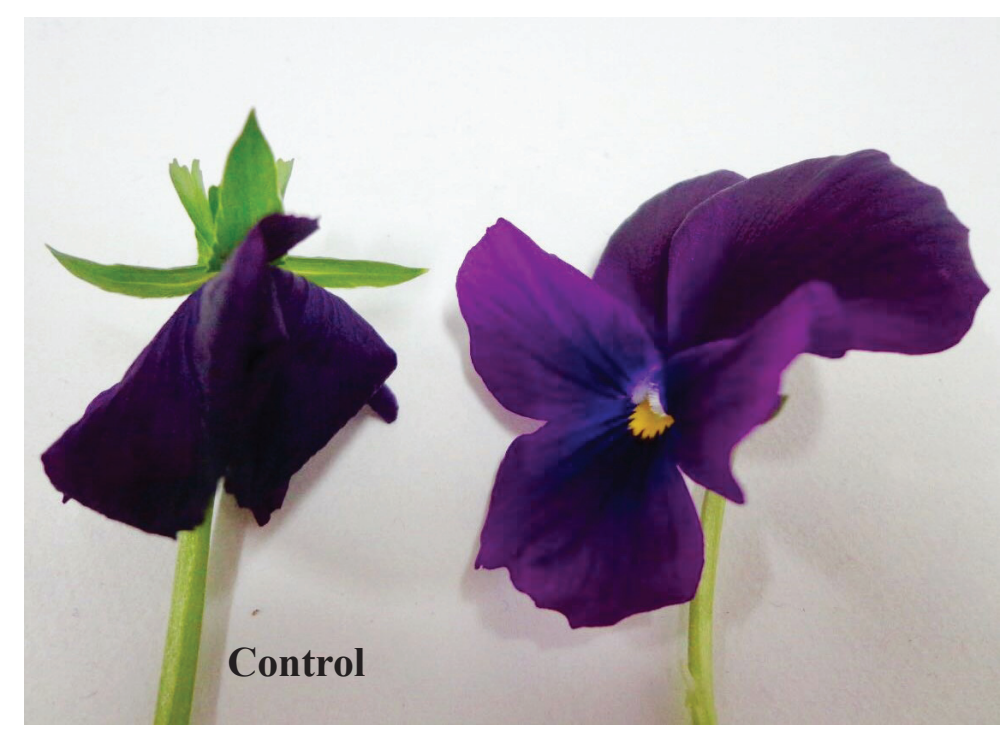

Figure 4. Appearance of wild pansy flowers (Viola tricolor) after 48 hours from application of $1.5 \mu \mathrm{L} \mathrm{L}^{-1}$ of 1-MCP and control.

Similarly, when 1-MCP was used in combination with ethylene, the flowers of both the solely ethylene and control treatment were in advanced senescence process (Table 1) denoted by negative grades in the senescence scale; as well as exhibiting greater fresh weight loss when compared to treatments with 1-MCP (Figure 3). Therefore, the fresh weight variation is directly related to the degree of the flower senescence. These results show that $1-\mathrm{MCP}$ is beneficial in maintaining the turgescence of wild pansy flowers, even in the presence of exogenous ethylene (Table 1).

The fresh weight loss over the course of days showed that the treatment for one minute with ABA induced similar fresh weight loss among treatments (Figure 5).

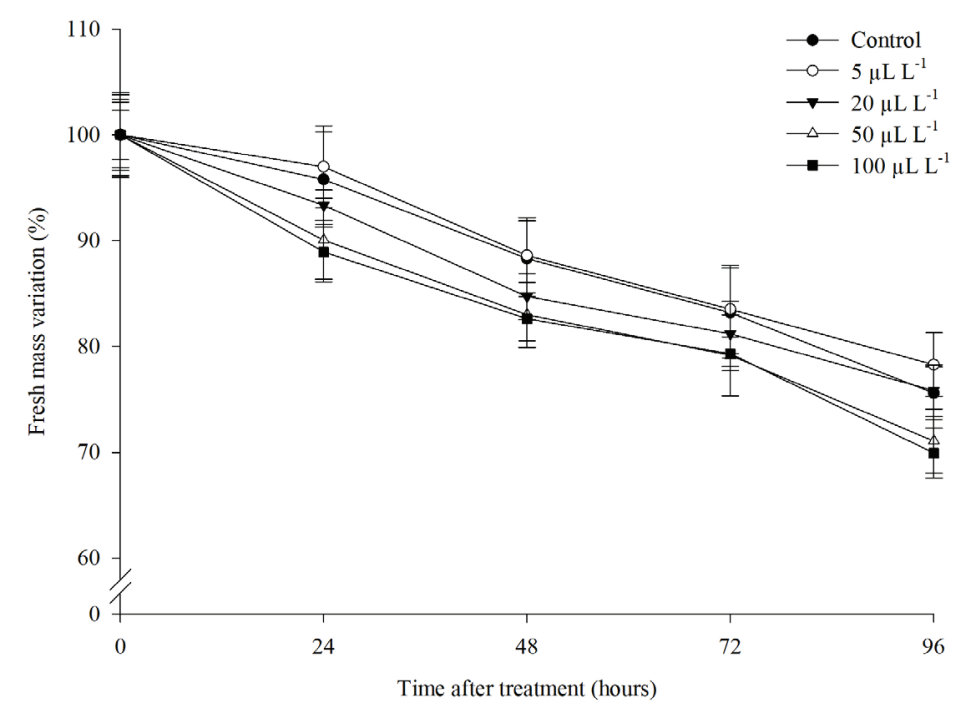

Figure 5. Fresh mass variation (\%) in heartsease flowers (Viola tricolor) over time, after the application of different doses of ABA $(\mu \mathrm{M})$. Bars represent standard error. 
At the end of the experiment, the flowers lost close to $20 \%$ of their weight. Senescence progress of ABA treated flowers showed differences, where higher concentrations of ABA led to faster flower senescence (Table 1). Thus, these results indicate that ethylene may not be directly involved in the senescence of these flowers; nevertheless, ABA may be involved by inducing events related to the senescence of wild pansy flowers.

Unlike ethylene-sensitive flowers, whose floral senescence is regulated at least in part by ethylene, wild pansy flowers seem to be insensitive to this hormone. However, the factors that lead to senescence in this group of flowers have not yet been elucidated. Data from previous works suggest that $\mathrm{ABA}$ may play an important role in the senescence of ethylene-insensitive flowers (ZHONG and CIAFRÉ, 2011). Recent studies have shown that an increase in $\mathrm{ABA}$ concentration occurs in the petals during senescence stages of ethylene insensitive flowers (KUMAR et al., 2014). According to Zhong and Ciafre (2011), there is a direct role of the ABA in the positive regulation of the initial steps of senescence of the petals, independently of the endogenous levels of ethylene.

\section{CONCLUSIONS}

Ethylene did not induce senescence of wild pansy flowers, but 1-MCP provided longer longevity on cut wild pansy flowers.

\section{ACKNOWLEDGMENTS}

The authors are grateful to the National Council for Scientific and Technological Development (CNPq) for financial support.

\section{AUTHORS CONTRIBUTIONS}

T.P.S.: Literature review, installation, conduction and evaluation of the experiment, data collection, laboratory analysis, interpretation of data, statistical analysis, manuscript preparation and review. F.F.A.: Interpretation of data, statistical analysis, write and critically analysis of manuscript. F.L.F.: Creation of the idea, obtaining the funding and materials, orientation and coordination of the study, as well as, important suggestions to the manuscript final version.

\section{REFERENCES}

DUKOVSKI, D.; BERNATZKY, R.; HAN, S. Flowering induction of Guzmania by ethylene. Scientia Horticulturae, v.110, p.104-108, 2006. DOI: http://dx.doi. org/10.1016/j.scienta.2006.05.004

HASSAN, F.A.S. The Role of 1-methylcyclopropene (1MCP) in improving the postharvest quality of some cut rose cultivars. Journal of Ornamental Plants, v.6, p.261-270, 2016. DOI: http://doi.org/10.1016/j.scienta.2013.12.015

HATAMZADEH, A., HATAMI, M.; GHASEMNEZHAD, M. Efficiency of salicylic acid delay petal senescence and extended quality of cutspikes of Gladiolus grandiflora cv 'Wing's Sensation'. African Journal of Agricultural Research, v.7, p.540-545, 2012. DOI: http://doi. org/10.5897/AJAR11.962

HUNTER, D.A.; FERRANTE, A.; VERNIERI, P.; REID, M.S. Role of abscisic acid in perianth senescence of daffodil (Narcissus pseudonarcissus 'Dutch Master'). Physiology Plantarum, v.21, p.313-321, 2004. DOI: http://doi.org/10.1111/j.0031-9317.2004.0311.x

KUMAR, M.; SINGH, V.P.; ARORA, A.; SINGH, N. The role of abscisic acid (ABA) in ethylene insensitive Gladiolus (Gladiolus grandiflora Hort.) flower senescence. Acta Plant Physiology, v.36, p.151-159, 2014. DOI: http:// dx.doi.org/10.1007/s11738-013-1395-6

TRAINOTTI, L.; PAVANELlO, A.; CASADORO, G. Different ethylene receptors show an increased expression during the ripening of strawberries: does such an increment imply a role for ethylene in the ripening of these nonclimacteric fruits? Journal of Experimental Botany, v.56, p.2037-2046, 2005. DOI: https://doi.org/10.1093/jxb/ eri202

VAN DOORN, W.; WOLTERING, E.J. Physiology and molecular biology of petal senescence. Journal of Experimental Botany, v.59, p.453-480, 2008. DOI: http:// doi.org/10.1093/jxb/erm356

ZHONG, Y.; CIAFRE, C. 2011. Role of ABA in ethyleneindependent Iris flower senescence. In: International conference on food engineering and biotechnology. IPCBEE, v. 9. Singapore: IACSIT Press. 